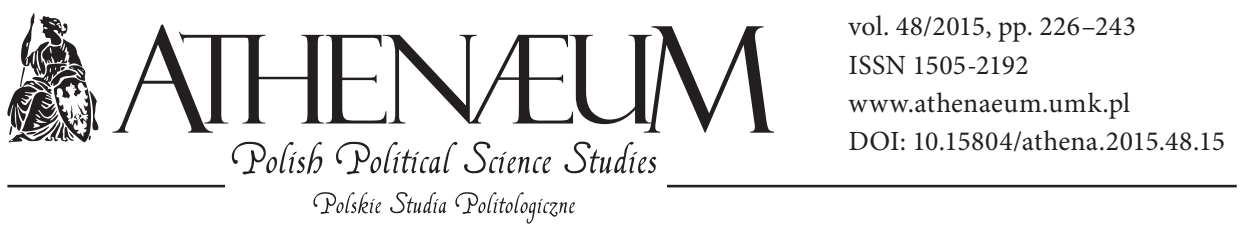

\title{
EFFICIENCY OF STATE FOREIGN POLICY. INTRODUCTION TO DEFINITION PROCESS*
}

\author{
Joanna Piechowiak-Lamparska**
}

\begin{abstract}
The aim of this article is to present the definition of efficiency of state foreign policy. As a result of theoretical research, the definition of efficiency that views efficiency of state foreign policy as the relationship between the intended objectives and the achieved effects, taking into account the resources used and measures adopted in the pursuit of these objectives. It is the sum of the component efficiencies in achieving the country's raison d'etat, its long-term and short-term objectives and ad hoc goals, and finally the level of state activity in the international arena
\end{abstract}

\section{KEYWORDS}

efficiency of state foreign policy, theoretical category, definition process, efficiency, effectiveness

\section{DEFINITIONS IN THE THEORY OF INTERNATIONAL RELATIONS}

Creating new knowledge in the field of international relations nowadays is full of difficulties. Both in deepening of the existing categories and in expansion of theoretical models and tools, the epistemological perspective has become extremely important in contemporary research. Multiplicity of available theoreti-

* This publication is a part of the scientific project "Strategic Partnership between a State and an International Organization: An Ideal Model” (the project was funded from the National Science Centre funds granted by decision No. UMO-2013/11/D/HS5/01260).

** Nicolaus Copernicus University in Toruń, Faculty of Political Science and International Studies. 
cal approaches largely hinders the process of drawing conclusions or making inferences in the study of international relations. The need to acquaint oneself with the pre-existing knowledge and achievements and, above all, their critical analysis significantly broaden the research framework wherein one has to position one's own research, and thus requiring definition. We should therefore focus on either the most influential theories, or those particularly close to the specific topic or issue. The category of efficiency has direct theoretical and empirical relevance, which means that a theoretical model can be applied and used in empirical considerations. Research in international relations offers both a chance for meta-level discussions, and for implementation of basic research.

The root of epistemological problems in theory of international relations seem to be primarily errors in formulating definitions of basic notions and phenomena. Janina Kotarbińska (1955) points out that „confusion in a theoretical discipline is always a bad thing. Confusion in logic, one of whose main tasks is precisely to counter and combat confusion is particularly bad. Confusion in the theory of definitions - the main tool in our fight against confusion - is very simply a mortal sin". This statement was intended as applicable to logic, but it can also equally easily be applied to any other discipline. Also Jan Zimmermann (2009) - in the context of defining terms within administrative law - states that „confusion and disarray in terminology [...] are significant. This creates a natural demand for introducing order into the field, and defining terms and concepts using permanent legal definitions. [...] Establishing a too narrow or a too broad definition may have very far-reaching consequences and cause vast disagreements and arguments in application of specific legal provisions". Therefore, at the initial stage in creation of a model, one needs to precisely define the object of research and the methods and techniques to be used.

The process of formulating definitions is burdened with many requirements and sub-stages. The first issue is the decision on the intended function of a given definition, and therefore the purpose of defining. In this paper, the main intention and aim is to give a new meaning to the term efficiency of state foreign policy. Given both the complex nature of the definiendum, and the difficulties associated with an attempt at specifying all objects or subsets falling under such a definition, the author shall endeavor to formulate a normal (intensional) definition, and not a partial (extensional) one. Stefan Nowak (1970: 74) points also to the fact that this choice is natural where "the scope of the generally accepted meaning of a given term is either internally heterogeneous, or indistinguishable from certain phenomena that are outside the range of that meaning to such 
an extent that building an adequate description which would attribute certain properties and characteristics to all objects within that range and only to these objects is not possible". The significance of the term efficiency is precisely that: very heterogeneous and ambiguous, and consequently remains open. However, one can still distinguish the necessary and sufficient condition (see Nowak 1970: 76-77) for belonging to the set being defined: which is for the [W1] ratio of value of achieved results to value of expenditures to be a ratio exceeding 1 .

The proposed definition is of a synthetic nature, and is one stipulating the meaning of the defined term. Immanuel Kant in his Critique of Pure Reason (published in Poland as Krytyka czystego rozumu, 2013) distinguishes - among the four types of propositions - synthetic a posteriori propositions, and consequently definitions that contain knowledge validated by and grounded in facts. At the same time, the posited definition is a border-line case according to Peter Unger (1979: 117-154), as it refers to a set of designates that do not exist in reality. It is important to recognize that any definition adopted must be a sum of designates sufficient to determine the object of research - that is to accept that the definiens can not be broader than the definiendum. In the context of social sciences research, encompassing also the study of international relations, Nowak (1970: 81) states that „for a definition of a given term to be considered satisfactory, it is sufficient for this definition to clearly describe the characteristics and criteria for belonging to the set being defined, that is the necessary and sufficient conditions permitting to distinguish the designates of a specific term from objects or phenomena that are not members of this set. Anything else that we want to add to any definition understood in these terms, no matter whether we want to specify conditions or features characteristic only for the set being defined, or those that the given set shares with other, external sets, should be considered as excessive or superfluous to the definition of a given term".

As indicated by Martin Kahl (2013: 35-60) in his article Causes, Effects and Effectiveness - Conceptual, Epistemological and Methodological Considerations, the term effectiveness in the ordinary, common meaning of the word can be understood as the degree to which a given goal is achieved by individual actors, instruments or policies. Such a broad interpretation of the meaning of the term effectiveness results in its ambiguity, and renders it highly imprecise. In the context of political science, one can therefore discuss effectiveness as a feature of a given politician, state or organization, but discussions on effectiveness of individual actions or activities - for example, effectiveness of sanctions imposed or of solutions incorporated into the legal framework - are equally valid. We 
often encounter this term - used with positive or pejorative connotations - also in the context of politics itself, in the Weberian sense of the word, where politics means the pursuit of power over a state or (pursuit for) influencing the division of power.

\section{CATEGORY OF EFFICIENCY IN SCIENCE DISCIPLINES}

\subsection{Terminological issues. Effectiveness versus efficiency}

Theoretical category of efficiency of state foreign policy is not described clearly and unambiguously in literature. The first issue that needs clarification is therefore the problem of terminology, associated with the frequent interchangeable use in Polish-language literature, in particular that on political science, of the terms of effectiveness and efficiency. English-language publications pose no similar problem, as the term efficiency usually means both efficiency and effectiveness as an incorporated element thereof. However, in economics it is common to use the term effectiveness in its narrower, more precisely defined meaning (see Clark 2000:3-25). Similar solution can be found in German literature - the term Effektivität there also means both efficiency and effectiveness. In broad terms, both efficiency and effectiveness mean achieving a positive result, a desired effect.

However, Józef Kukułka (1978: 23-55) and Terasa Łoś-Nowak (2006: 236-245) give these terms two separate meanings. Effectiveness of state foreign policy is shown in the actions undertaken having achieved the desired results - therefore this term applies more to assessment of the final outcome. Efficiency of foreign policy on the other hand is manifested not only in the result itself, but also in the degree to which the resources at one's disposal have been used. This difference lies, in short, in the term efficiency being broader than that of effectiveness, as a wider range of components of a decision-making process and the resulting action is covered by the evaluation inherent in the term efficiency (not only the outcome or output as such, but also avoidance of waste in achieving it).

It seems, therefore, that the category of efficiency is multidimensional, as designating something as efficient is the culmination of a process where at the end an analysis of the ratio between the effects achieved to the expenditure incurred is performed; the level of efficiency is then assessed using a predetermined measurement scale. Efficiency may have an economic, social or political dimension. Figure 1 below shows the process of efficiency analysis, while 
Figure 2 presents how effectiveness of an action is analyzed. It should be noted that the first three steps of both models are the same - it is necessary first to define the goals of an action, determine the resources held and available for use, and finally define the action per se. With high probability it can be assumed that, due to partially isomorphous nature of both these processes, efficiency and effectiveness are often mistakenly used as synonyms. However, their similarity ends at the stage of analysis itself.

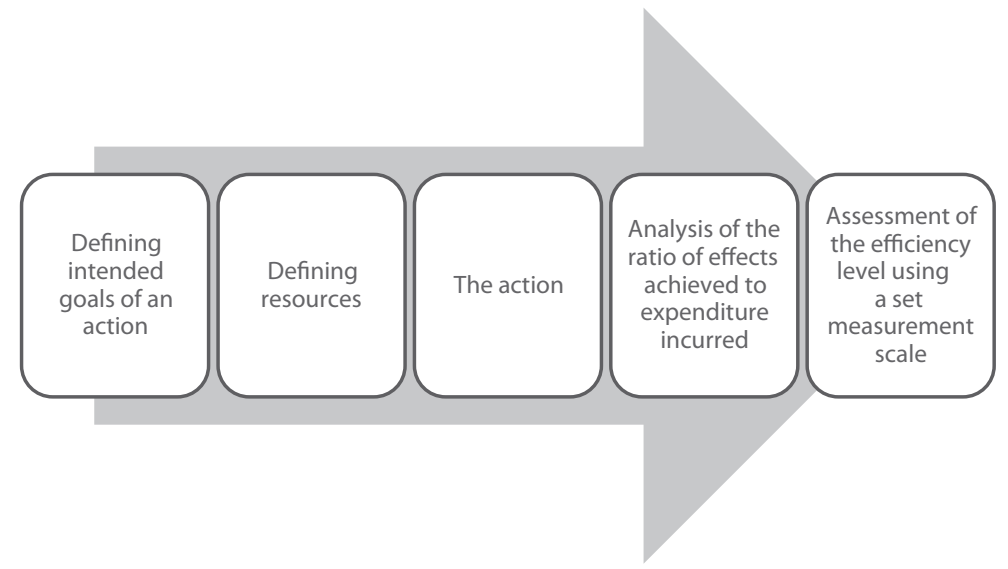

Figure 1. A simple model for analysis of efficiency of an action

Source: Own research.

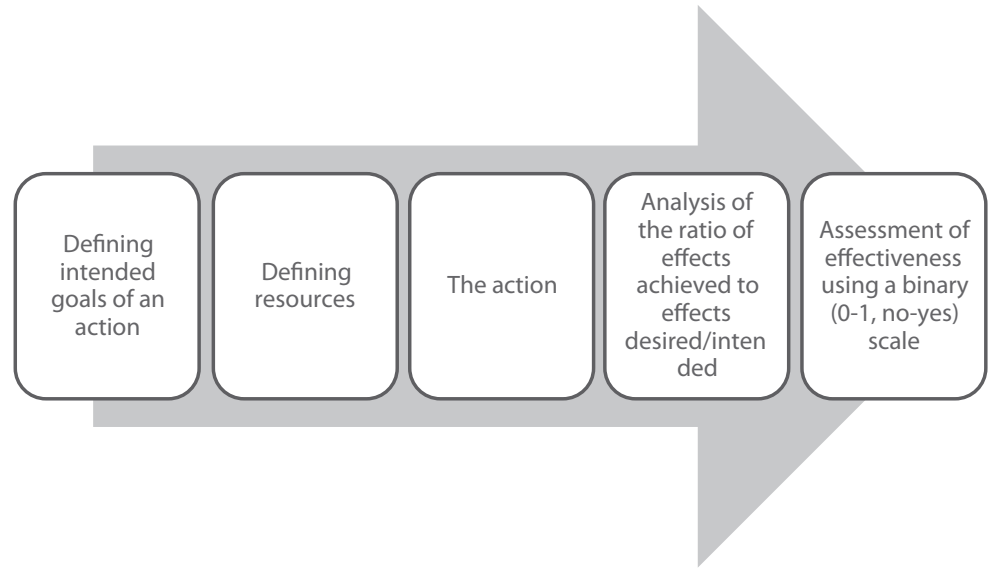

Figure 2. A simple model for analysis of effectiveness of an action

Source: Own research. 
In order to solve this issue, the use of both these terms in parallel, as interchangeable, is often sanctioned. However, due to the need to precisely define the category of efficiency for the purpose of this paper, it is imperative that a clear distinction between efficiency and effectiveness is made. As indicated by Agnieszka Bryc (2009: 193), „,it can be considered acceptable to apply the concepts of efficiency and effectiveness as synonymous, with the exception of cases where a more detailed analysis is required".

\subsection{Efficiency in economics}

The notion of efficiency defined as the ratio of effect or output versus expenditure or input (in production terms) is used in economics at the macro-, meso- and micro-scale. This category, thanks to its wide application options, is from a cognitive point of view highly versatile, if not entirely universal, as it can provide an understandable description of certain key features of many phenomena. The efficiency index or ratio is a relative magnitude of two selected numerical values, and thus is conditioned by the selection of indicators used.

The purpose of the present paper is not to perform a comprehensive analysis of the category of efficiency within the framework of economic sciences, as this could in fact constitute a topic for a separate, long article.

However, it is necessary to present how the term efficiency is understood in strictly economic terms in order to allow for its correct application in the area of transnational relations. The above means specifying such constitutive features and criteria for this category that will be universal or sufficiently multidimensional for an interdisciplinary application. One must bear in mind though that there is no single, universally accepted definition of efficiency (see KozunCieślak 2013a: 157-181). It is the author's deliberate choice not to present below the various efficiency definitions and ratios, and the corresponding mathematical formulas that can be (and are) used in studies at a micro- or meso- scale. In macro-economic analysis such specific and detailed definitions of various dependencies are not widespread. One of the main reasons for this is the impossibility of gathering huge amounts of data and entering them into the algorithm, or - alternatively - fragmented nature or inaccessibility of the data. Of course, research at the macro-level still holds significant cognitive value - its particular nature is simply different, and consequently requires the use of a different set of indicators, ratios and formulas. 
Despite the ambiguity and multiplicity of meanings of the discussed terms, one can attempt to consolidate these varying definitions into several semantic groups, dividing the possible relationships between the categories of efficiency and effectiveness into clearer types. Grażyna Kozuń-Cieślak (2013b: 14-15) distinguishes five main types of relationships between these concepts: effectiveness as a condition/element for achieving efficiency, efficiency as a criterion for measuring effectiveness, efficiency and effectiveness as independent categories, efficiency as productivity/yield and efficiency in terms of allocation of resources (Pareto efficiency). It seems that the greatest interpretation concerns arise in the case of viewing efficiency as conditioned by effectiveness. Wojciech Gasparski (2008) emphasizes that measures undertaken in the economic sector in order to be efficient must be both effective and economical (read: cost-effective), with the value of effects or results achieved exceeding the value of costs incurred, while still keeping in mind that the measures undertaken must fit „within the framework defined by the social axiomatic context, where society offers conditional approval for the selection of objectives and measures of their attainment dependent on their ethical nature". On the other hand, Stanisław Nowosielski (2008: 41) differentiates two meanings of the term efficiency depending on the intended scope of components taken into account in assessment of efficiency. And thus, efficiency sensu largo combines effectiveness, expediency and economy (cost-effectiveness), while in its sensu stricto meaning it refers only to the costeffectiveness of a given action. Despite the fact that the above approaches seem quite varied, they are all equally valid and cannot be called into question as they are all grounded in economic theory and practice.

The approach to the category of efficiency has evolved over time, from a simple cost-effectiveness ratio of a given action to a multi-dimensional analysis, involving not only the financial and organizational context, but also the moral one. One of the underlying reasons is the fact that the term profitability itself also took on a broader meaning, going beyond the initial purely financial, revenue-centered aspects. Maria Holstein-Beck $(1987 ; 1997)$ discussed the above mentioned evolution and change in how these terms are understood. Analysis of this process is important for attempts to translate or redefine the meaning of efficiency formulated in economic terms into one applicable to political science as well.

Categories of efficiency - the possible ranges of meaning that can be used to measure efficiency - differentiated by Maria Holstein-Beck are as follows:

- Performance - in the context of Harington Emerson's technical and economic approach; 
- Competence - as per the organisational and bureaucratic approach of Max Weber and Richard Beckhard;

- Proficiency - in the context of praxiological approach developed by Tadeusz Kotarbiński and Tadeusz Pszczółkowski;

- Functionality - humanist approach of Douglas McGregor, James L. Price, and David J. Lawless;

- Communicativeness - personality approach developed by Burt K. Scanlan and Kazimierz Obuchowski;

- Morality - in the context of environmental responsibility.

Efficiency in economic terms can be directly and simply separated from effectiveness. Economic processes are characterized by a certain purposefulness, which allows for subsequent evaluation of the actions and measures taken. This assessment takes place on two levels: the first is whether the set objectives have been attained (goals can be achieved or not, a binary choice) - thus in fact evaluating effectiveness; with the second involving the question of the ratio of input (expenditure or costs) to the achieved effects (effects or output may exceed the costs, or be inferior/of lower value in comparison), and therefore considering efficiency as such.

As shown in Table 1, the outcome of actions or measures undertaken in economic process might thus be: 1) effective and efficient; 2) effective and inefficient; 3 ) ineffective and efficient; and finally 4) ineffective and inefficient (cf. Nowosielski 2008: 39-46). In optimal conditions, a process may be classified as both effective and efficient.

Table 1. Typology of economic processes and phenomena in terms of their efficiency and effectiveness

\begin{tabular}{|l|l|l|}
\hline PROCESS & EFFICIENT & INEFFICIENT \\
\hline EFFECTIVE & $\begin{array}{l}\text { Planned goals are achieved during the } \\
\text { process } \\
\text { Output (effects) exceeds costs (input) }\end{array}$ & $\begin{array}{l}\text { Planned goals are achieved during the } \\
\text { process } \\
\text { Costs (input) exceed output (effects) }\end{array}$ \\
\hline INEFFECTIVE & $\begin{array}{l}\text { Planned goals are not achieved during } \\
\text { the process } \\
\text { Output (effects) exceeds costs (input) }\end{array}$ & $\begin{array}{l}\text { Planned goals are not achieved during } \\
\text { the process } \\
\text { Costs (input) exceed output (effects) }\end{array}$ \\
\hline
\end{tabular}

Source: Own work elaborated on the basis of: S. Nowosielski 2008: 39-46.

The foundations of the theory of economic efficiency in conditions of perfect competition were laid by Vilfredo Pareto. This theory is based on the belief that the 
conditions for efficiency are satisfied only when no improvement in the utility of a consumer is possible without a worsening of the utility of some other consumer (see Barr 2012: 46-49; Kozuń-Cieślak 2013a; Kozuń-Cieślak 2013b; Szudy, 2014; Rutkowska 2013: 443-444). As explained by Nicholas Barr (2012: 46), „Pareto efficiency incorporates two value judgements: 1) social welfare is increased if one person is made better off and nobody worse off; and 2) individuals are best judges of their own welfare". This means that the common good, interpreted as public interest, cannot be upheld. Due to its harsh conditions, Pareto efficiency (Pareto optimum) may be useful only in terms of a finite set of alternatives, for example in power engineering or in vector problems (see Tomoiagă, Chindriş, Sumper, Sudria-Andreu \& Villafafila-Robles 2013: 1439-1455; Godfrey, Shipley \& Gryz 2006: 5-28). However, the notion of Pareto efficiency cannot be applied to social science, as situations meeting the perfect and strict conditions set out by Pareto are impossible.

An attempt to adjust the theory of efficiency according to Pareto to reallife criteria is the so-called Kaldor-Hicks efficiency, known also as Kaldor-Hicks improvement. As Nicholas Kaldor (1939: 549-552) and John Hicks (1939: 696-712) posit, a resource allocation could be considered efficient after all if those that are made better off could hypothetically compensate those that are made worse off (whose utility was worsened). In this model, the issue of social justice is taken into account, but this method of judging economic reallocations of given resources still remains applicable to a limited number of circumstances.

Efficiency in terms of economic science is treated primarily as a category denoting cost-effectiveness of a given action (cf. Barburski 2008: 31-56) or profitability of activities undertaken by a person or an entity, for example by an enterprise (see Kulawik 2010: 43-63; Szymańska 2010: 152-164). Such a definition of the category of efficiency refers purely to financial and production dimensions - that is, the domain of economics. However, it is only one of the many possible meanings of this term; it can also be applied in the area of politics, communication, interpersonal relations or praxiology. It should be emphasized that an attempt to use or adapt economic indicators in political science analyses would be pointless. 


\subsection{Efficiency in political sciences}

A much greater problem, extending across a wide range a research areas, is the issue of key elements of definition of efficiency in state foreign policy. The process of efficiency assessment is in itself a multi-component phenomenon, permanently embedded in a particular scientific paradigm. The specific dynamics of both international relations themselves, as well as of studies devoted to these relationships force researchers - to a certain extent - to incorporate an increasing number of components in this analysis. Among the many factors shaping the geopolitical sphere of the modern world one should name - after Józef Kukułka (2010: 219) - inter alia political factors, military, economic, cultural components, technological, ideological and ecological factors; of course, aspects such as energy, access to raw materials, logistics or religion should not be neglected either. It must therefore be assumed that ,a dynamic, multi-component approach to processes of international relations shows that at the core, their main purpose is to satisfy - to the maximum degree possible - the needs, interests and objectives of various actors in international relations (states, international organizations and institutions) in the course of developing their mutual relations" (Kukułka 2010: 219).

As the most important theories of international relations of the $20^{\text {th }}$ and $21^{\text {st }}$ centuries are considered the theories of realism and neo-realism, liberalism and neo-liberalism and the postmodern theory. Each of these paradigms presents a different approach - not to the efficiency of foreign policy as such, but to the hierarchy of objectives, modes of action, objects of such action and tools employed. Each of these models also uses a different method to assess the outcomes of a given action (see Łoś-Nowak 2006: 84-85; Czaputowicz 2008: 50). The meaning of the term efficiency remains constant across all of the above presented theories. The choice of a specific model was usually dictated by which theory at the time was enjoying greatest popularity in the study of international relations, and was the dominant paradigm.

The issue of determining what exactly is meant by the term efficiency of state foreign policy is an extremely complex and multidimensional matter. After all, analysis and assessment of actions directed at other subjects of international law should be based primarily on a theoretical model of efficiency of national foreign policy. The most important goal of the research conducted is therefore to analyze the role and potential of state foreign policy and the strategy pursued by the state in the international arena, as well as to assess the consequences of these actions. 
Foreign policy is a tool used by the state to satisfy its needs and interests on the international arena. Its evaluation should be placed on the axis traced between two ideal types at the opposite ends of the scale (vide Weber 1995; Załęski 2003: 45-51; Bäcker 2011: 201-213; Bruun 1972; Wolin 1981: 401-424): one being foreign policy carried out in an ideally efficient manner, the other - perfectly inefficient foreign policy. Inefficient external policy means actions undertaken are ineffective, unprofitable and badly-suited to the objective pursued and inconsistent with the raison d'etat. In contrast, efficient foreign policy is characterized by full satisfaction of the needs and interests of the state (objectives are achieved at all levels). The level of efficiency of foreign policy should be examined from the perspective of strategies governing the undertaken actions, the tactics adopted and the (right) selection of methods and tools for its implementation. Between the extremes of entirely inefficient and efficient external policy, there are many models with a varying degree of inefficiency (or, from a different point of view, efficiency). It is therefore necessary to create precise criteria describing perfectly (in)efficient foreign policy of a state.

Efficiency of foreign policy should be tested in parallel on two levels - in terms of available resources and means, and the end result of measures employed or actions taken. Only combining these two aspects allows to create a full picture and perform a comprehensive assessment of the role and position of a given state in the international arena. Analysis of the resources available to be employed in external actions of a state should be based on a detailed description of its diplomatic and military potential and level of access to raw materials and other resources. Assessment of the final outcome, on the other hand, requires verification of the degree to which the available resources were used and how well they were employed in real-life situations on the international arena.

To systematize the wide field of external activity of a state, it is necessary to divide foreign policy into the domains of bilateral relations, multilateral relations and global relations (see Haliżak 2014: 19-30; Thompson 2013; Stone, Slantchev \& London 2008: 335-362; Saggi \& Murat Yildiz 2010: 26-37; Rixen \& Rohlfing 2007:389-414). At the bottom of the pyramid, as the most natural, primary relationships, are the relations between two partners - they enable the attainments of particular interests (vide Łoś-Nowak 2014: 89-112; Rixen 2010: 589-614; Blum 2008: 323-379). Such fundamental significance of bilateral relations is also justified historically, as the first multi-party intergovernmental organizations in their modern meaning were created only in the $19^{\text {th }}$ century, much later than states began to establish bilateral contacts (vide Łoś-Nowak 2004: 38-39; Bierzanek 
\& Symonides 2008: 285-336; Pietraś 2006: 92-118; Ruggie 1992: 561-598). Subsequently, multilateral relations at a regional level (cf. Zajączkowski 2014: 65-88; Bojarczyk, Czarnocki, Dumała, Krzywicka, Maj, Topolski \& Ziętek 2014: 238-273), followed by global-level interactions were established. Despite the clearly apparent importance of regional relationships, with neighboring countries associated in relevant regional organization (such as the Visegrad Group and GUAM - Organization for Democracy and Economic Development), most often they are not a national priority. Instead, inter-governmental organizations with a global reach (such as NATO, the EU or the UN), due to their extensive influence are considered to be crucial partners for a state and, as remarked Kalevi J. Holsti (2004: 184), are in fact responses to the weak state.

Some researchers argue that efficiency of policy can not be viably analyzed at all. Mirosław Sułek (2010: 57) concludes that efficiency in international politics is impossible to measure. He points out that „analysis of efficiency has its origin in economic calculations, established to meet the needs of companies operating in a free market which determines the prices of goods and services. This allows to determine whether production is profitable, and what is its specific efficiency, i.e. the ratio of output to input. A similar mechanism does not work in the sphere of international politics, thus there are no parameters allowing for efficiency analysis in this context. Even if we assume that the strength of a state should be taken as its currency, we still do not know what can it buy with a given amount, or what price should be set when selling something. In short, we do not know sufficiently clearly what the effects or results are, or what specific outlays or costs are borne; therefore assessment of efficiency in politics is rendered basically impossible". While it is certainly true that the sphere of transnational political relations is separate from the economic domain, such an approach appears not to take into account the possibility of a different definition of efficiency than that relating to financial and organizational issues. Table 2 shows various types of efficiency assessment, assuming outlays and results are clearly distinct (observed as different stages). It should be noted, however, that the approach presented by Mirosław Sułek ignores in the analytical assessment procedure the category of objectives. A take on efficiency viewing it as shaped by three factors: 1) objectives, 2) outlays and 3) results is a much more comprehensive approach than one based solely on the outlays versus results ratio.

Issues related to purposefulness (focus on objectives) of a country's foreign policy are also raised by Agnieszka Bryc (2009: 196). The author states that „evaluation of foreign policy efficiency consists in comparing the start versus 
Table 2. Categories of outlays, results and efficiency

\begin{tabular}{|l|l|l|}
\hline OUTLAYS & RESULTS & EFFICIENCY \\
\hline $\begin{array}{l}\text { Well defined } \\
\text { (measurable) }\end{array}$ & $\begin{array}{l}\text { Well defined } \\
\text { (measurable) }\end{array}$ & $\begin{array}{l}\text { Well defined (measurable) } \\
\text { - cost and profit (results) assessment }\end{array}$ \\
\hline $\begin{array}{l}\text { Well defined } \\
\text { (measurable) }\end{array}$ & $\begin{array}{l}\text { Insufficiently } \\
\text { defined } \\
\text { (non-measurable) }\end{array}$ & $\begin{array}{l}\text { Insufficiently defined } \\
\text { (non-measurable) } \\
\text { - cost analysis }\end{array}$ \\
\hline $\begin{array}{l}\text { Insufficiently } \\
\text { defined } \\
\text { (non-measurable) }\end{array}$ & $\begin{array}{l}\text { Well defined } \\
\text { (measurable) }\end{array}$ & $\begin{array}{l}\text { Insufficiently defined } \\
\text { (non-measurable) } \\
\text { - result (profit) analysis }\end{array}$ \\
\hline $\begin{array}{l}\text { Insufficiently } \\
\text { defined } \\
\text { (non-measurable) }\end{array}$ & $\begin{array}{l}\text { Insufficiently } \\
\text { defined } \\
\text { (non-measurable) }\end{array}$ & $\begin{array}{l}\text { Insufficiently defined } \\
\text { (non-measurable) } \\
\text { - „political” analysis and assessment }\end{array}$ \\
\hline
\end{tabular}

Source: Sułek 2010: 57.

end state, that is the objectives declared at the onset with the progress of their implementation in the period considered, taking into account the conditions (both positive and negative) in the international environment, and assuming the optimal selection of methods and means". In light of the above comments, state foreign policy can in fact be analyzed in terms of efficiency. However, the principle underlying all such discussions must be well-grounded in the context of a particular paradigm; it is imperative to define what exactly is input in terms of international relations, and what is output. One should also keep in mind that ,assessment of efficiency of state foreign policy is quite ambiguous. This characteristic is mainly due to the fact that the categories of analysis include both measurable (quantifiable) and immeasurable (unquantifiable) factors, often listed subjectively by the individual researcher, thus making the final evaluation less precise and rather biased" (Bryc 2009: 206).

The approach to the category of efficiency of foreign policy emphasizing both its importance and inherent difficulties in its definition is the prevalent one among political science researchers. Still, also in the area of political science it is necessary to distinguish the notions of efficiency and effectiveness of foreign policy. Figures 5 and 6 below show simplified models for analysis of, respectively, efficiency and effectiveness of actions taken in international politics. Assessment of efficiency consists in joint examination of three separate elements, while evaluation of effectiveness applies only to assessing the results or consequences of measures adopted. 


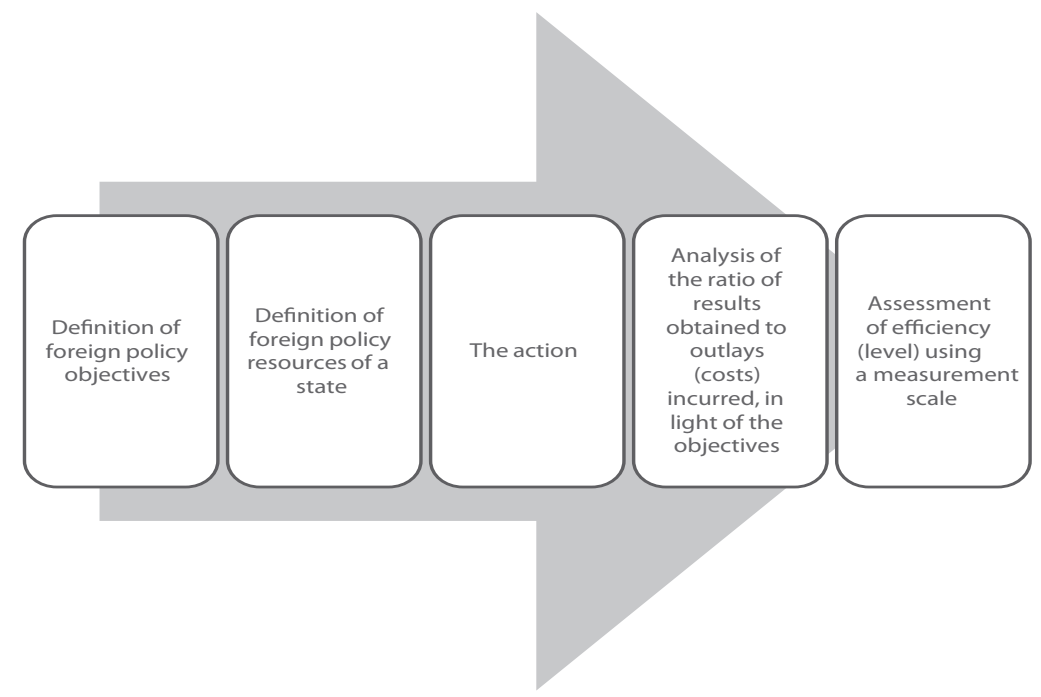

Figure 3. A simple model for assessment of efficiency of state foreign policy

Source: Own research.

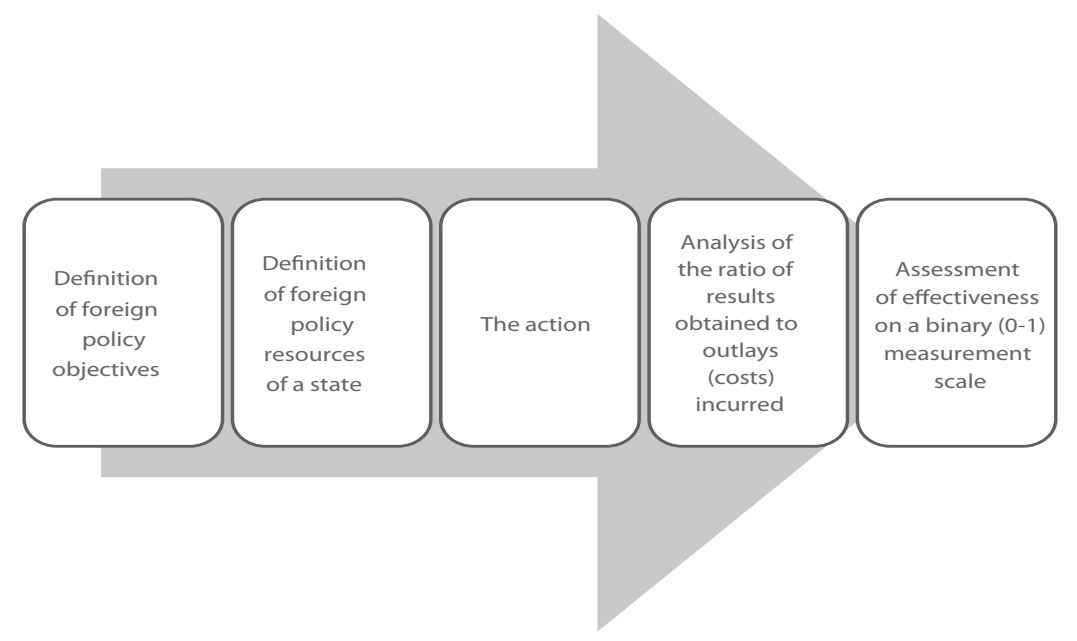

Figure 4. A simple model for assessment of effectiveness of state foreign policy

Source: Own research. 


\section{Conclusions}

Creation of a theoretical category of state foreign policy is fraught with difficulties. However, the basic definition, the lowest common denominator all would agree on is that effective policy is one by which an entity or individual achieves the desired objectives at the lowest possible cost. Still, in formulation of a model, one must determine not only the ideal type (perfectly efficient policy), but also a number of types with a varying degree of inefficiency, with negative connotations.

As a result of theoretical research, the definition of efficiency that views efficiency of state foreign policy as the relationship between the intended objectives and the achieved effects, taking into account the resources used and measures adopted in the pursuit of these objectives. It is the sum of the component efficiencies in achieving the country's raison d'etat, its long-term and short-term objectives and ad hoc goals, and finally the level of state activity in the international arena.

Classes of efficiency of state foreign policy:

- Perfectly efficient foreign policy

- Partially efficient foreign policy

- Partially inefficient foreign policy

- Perfectly inefficient foreign policy

We should also be well aware of a large role of researchers in the study of efficiency. The range of meanings of the term efficiency goes far beyond the category of pure cost efficiency - hence many factors taken into account are dependent on individual assessment by the researcher. The defined category remains open, and it seems the epistemological field (episteme) is appropriate for the realities of the current international system. Hence the definiens should be left open, flexible, adaptable and responsive to the changes taking place in the modern world.

Due to dynamic development of the international system, it is extremely difficult to provide an iron-clad, certain catalog of factors and elements to be used in assessment of efficiency of state foreign policy. The complex nature of relations at a transnational level does not allow for the permanent placement of a given factor on such a list, and no list would be applicable to all circumstances. 


\section{REFERENCES:}

Bäcker R. (2011). O znaczeniu kategorii typu idealnego. [in:] Czym jest teoria $w$ politologii? Z. Blok (ed.). Warszawa: Emissio.

Barburski J. (2008). Ekonometryczny pomiar efektywności ekonomicznej instytucji finansowych. Stochastyczny model graniczny kosztów. "Bank i Kredyt" 1.

Barr N. (2012). Economics of the Welfare State. Hampshire: Palgrave Macmillan.

Bierzanek R. \& Symonides J. (2008). Prawo międzynarodowe publiczne. Warszawa: Wolters Kluwer.

Blum G. (2008). Bilateralism, Multilaralism, and the Architecture of International Law. "Harvard International Law Journal" 2.

Bruun H.H. (1972). Science, Values and Politics in Max Weber's Methodology. Copenhagen: Munksgaard.

Bryc A. (2009). Efektywność polityki zagranicznej państwa. [in:] Wstęp do teorii polityki zagranicznej państwa. R. Zięba (ed.). Toruń: Wydawnictwo Adam Marszałek.

Clark B. (2000). Managerial Perceptions of marketing Performance: Efficiency, Adaptability, Effectiveness and Satisfaction. "Journal of Strategic Marketing" 8.

Czaputowicz J. (2008). Teorie stosunków międzynarodowych. Warszawa: PWN.

Gasparski W. (2008). Decyzje i etyka. Norma uczciwości. Wystąienie na gali Filarów Polskiej Gospodarki „Pulsu Biznesu”., „Decydent \& Decision Maker” 74.

Godfrey P., Shipley R. \& Gryz J. (2006). Algorithms and Analyses for Maximal Vector Computation. "VLDB Journal" 16.

Haliżak E. (2014). Poziomy analizy w nauce o stosunkach międzynarodowych. [in:] Poziom analizy stosunków międzynarodowych. t. 1. E. Haliżak \& M. Pietraś (eds.). Warszawa: Wydawnictwo Rembler.

Hicks J. (1939). The Foundations of Welfare Economics. "Economic Journal" 196.

Holstein-Beck M. (1987). Szkice o pracy. Warszawa: Książka i Wiedza.

Holstein-Beck M. (1997). Być albo nie być menedżerem. Warszawa: Infor Book.

Holsti K.J. (2004). The State, War, and the State of War. Cambridge: Cambridge University Press.

Kahl M. (2013). Causes, Effects and Effectiveness - Conceptual, Epistemological and Methodological Considerations. [in:] Studying 'Effectiveness' in International Relations. H. Hehemann, R. Heller \& M. Kahl (eds.). Opladen-Berlin-Toronto: Barbara Burdich Publishers.

Kaldor N. (1939). Welfare Propositions in Economics and Interpersonal Comparisons of Utility. "Economic Journal" 195.

Kant I. (2013). Krytyka czystego rozumu. Toruń: Wydawnictwo Naukowe Uniwersytetu Mikołaja Kopernika.

Kotarbińska J. (1995). Definicja., Studia Logica” 2.

Kozuń-Cieślak G. (2013a). Efektywność - ewolucja koncepcji w retrospekcji teorii ekonomii. „Studia i Prace Kolegium Zarządzania i Finansów” 128.

Kozuń-Cieślak G. (2013b). Efektywność - rozważania nad istota i typologia. „Kwartalnik Kolegium Ekonomiczno-Społecznego Studia i Prace" 4. 
Kukułka J. (1978). Metody analizy polityki zagranicznej i jej efektywności. [in:] Teoretyczne problemy polityki zagranicznej. E.J. Pałyga \& J. Symonides (eds.). Warszawa: IGKR SGPiS.

Kukułka J. (2000). Teoria stosunków międzynarodowych. Warszawa: PWN.

Kulawik J. (2010). Efektywność przedsiębiorstw wielkotowarowych w rolnictwie. „Zagadnienia Ekonomiki Rolnej” 3.

Łoś-Nowak T. (2004). Organizacje w stosunkach międzynarodowych. Istota - Mechanizmy działania - Zasieg. Wrocław: Wydawnictwo Uniwersytetu Wrocławskiego.

Łoś-Nowak T. (2006). Stosunki międzynarodowe. Teorie - Systemy - Uczestnicy. Wrocław: Wydawnictwo Uniwersytetu Wrocławskiego.

Nowak S. (1970). Metodologia badań socjologicznych. Warszawa: PWN.

Nowosielski S. (2008). Skuteczność i efektywność realizacji procesów gospodarczych. [in:] Efektywność funkcjonowania szkół wyższych. T. Dudycz \& Z. Wilimowska (eds.). Wrocław: Wydawnictwo Indygo Zahir Media.

Pietraś M. (2006). Organizacje międzynarodowe. [in:] Międzynarodowe stosunki polityczne. M. Pietraś (ed.). Lublin: Wydawnictwo Uniwersytetu Marii Curie-Skłodowskiej.

Rixen T. (2010). Bilateralism or Multilateralism? The Political Economy of Avoiding International Double Taxation. "European Journal of International Relations" 16.

Rixen T. \& Rohlfing I. (2007). The Institutional Choice of Bilateralism and Multilateralism in International Trade and Taxation. "International Negotiations" 12.

Ruggie J.G. (1992). Multilateralism: The Anatomy of an Institution. "International Organization" 46.

Rutkowska A. (2013). Teoretyczne aspekty efektywności - pojęcie i metody pomiaru. „The Journal of Management and Finance" 1.

Saggi K. \& Murat Yildiz H. (2010). Bilateralism, Multilateralism, and the Quest for Global Free Trade. "Journal of International Economics" 81.

Stone R.W., Slantchev B.L. \& London T.R. (2008). Choosing How to Cooperate: A Repeated Public-Goods Model of International Relations. "International Studies Quarterly" 52.

Sułek M. (2010). Prognozowanie i symulacje międzynarodowe. Warszawa: Wydawnictwo Naukowe Scholar.

Szudy M. (2014). Efektywność ekonomiczna w ujęciu dynamicznym a sprawność systemu gospodarczego. „Studia Ekonomiczne” 176.

Szymańska E. (2010). Efektywność przedsiębiorstw - definiowanie i pomiar. „Rocznik Nauk Rolniczych, Seria G" 2.

Thompson A. (2013). Multilateralism, Bilateralism and Regime Design. Department of Political Science Ohio State University, Retrieved 23 September 2013.

Tomoiagă B., Chindriş M., Sumper A., Sudria-Andreu A. \& Villafafila-Robles R. (2013). Pareto Optimal Reconfiguration of Power Distribution Systems Using a Genetic Algorithm Based on NSGA-II. "Energies" 6.

Unger P. (1979). There Are No Ordinary Things. "Synthese" 41.

Weber M. (1995). Szkice z socjologii religii. Warszawa: Książka i Wiedza. 
Wolin S. (1981). Max Weber: Legitimation, Method, and the Politics of Theory. "Political Theory" 9.

Zajączkowski J. (2014). Poziom analizy regionalnej w nauce o stosunkach międzynarodowych. [in:] Poziom analizy stosunków międzynarodowych. t. 1. E. Haliżak \& M. Pietraś (eds.). Warszawa: Wydawnictwo Rembler.

Załęski P. (2003). Typy idealne w socjologii religii Maxa Webera: Analiza struktury kategoryzującej pole religijne. „Kultura i Społeczeństwo” 1.

Zimmermann J. (2009). Przepisy ogólne prawa administracyjnego i definiowanie pojęć. „Ruch Prawniczy, Ekonomiczny i Socjologiczny” 2. 